\title{
Management of pelvic heterotopic ossification post-myocutaneous flap reconstruction of a sacral pressure ulcer
}

\author{
Colin W Mclnnes BSc${ }^{1}$, Richard AK Reynolds MD², Jugpal S Arneja MD ${ }^{3}$
}

CW McInnes, RAK Reynolds, JS Arneja. Management of pelvic heterotopic ossification post-myocutaneous flap reconstruction of a sacral pressure ulcer. Can J Plast Surg 2011;19(2):60-61.

Heterotopic ossification $(\mathrm{HO})$ is a process whereby lamellar bone forms in the soft tissues surrounding a joint. The most common type of $\mathrm{HO}$ is traumatic myositis ossificans, which develops following traumatic injuries, burns or arthroplasty. A variety of other forms of $\mathrm{HO}$ also exist, such as those associated with central nervous system injury and systemic forms that can manifest at other joints simultaneously. Clinically, patients can present with decreased range of motion, pressure ulcers, nerve compression, swelling, pain or asymptomatically. Symptomatic patients are most commonly treated with surgical debridement of the affected heterotopic deposits.

Spinal dysraphism (SD) is a term describing a wide range of congenital malformations of the neural tube, ranging from spina bifida occulta to the more severe form, myelomeningocele. The cause of SD is multifactorial and has been associated with chromosomal disorders, teratogenic exposure and folate deficiency. Many patients with SD experience neuropathy below the affected neurological level, making them particularly susceptible to pressure ulcers. If these ulcers are severe and do not respond to conservative therapy, they often require surgical debridement and flap reconstruction - a clinical scenario that rarely results in $\mathrm{HO}$.

The present article describes a case involving a patient with pelvic $\mathrm{HO}$ following myocutaneous flap reconstruction of a pressure ulcer. The patient was successfully treated with oral bisphosphonate and aggressive physiotherapy.

Key Words: Heterotopic ossification; Pressure ulcer; Reconstructive surgery

\section{La prise en charge d'une ossification hétérotopique pelvienne après la reconstruction d'une plaie de pression du sacrum au moyen d'un lambeau myocutané}

L'ossification hétérotopique $(\mathrm{OH})$ est un processus par lequel des os lamellaires se forment dans les tissus mous entourant une articulation. Le principal type d'OH est une myosite ossifiante traumatique, qui fait sont apparition après des lésions traumatiques, des brûlures ou une arthroplastie. Il existe également diverses autres formes d'OH, telles que celles qui s'associent à une lésion du système nerveux central et à des formes systémiques qui peuvent se manifester systématiquement au foyer d'autres articulations. Sur le plan clinique, les patients peuvent présenter une diminution de l'amplitude de mouvements, des plaies de pression, une compression nerveuse, une enflure, des douleurs ou n'avoir aucuns symptômes. La plupart du temps, les patients symptomatiques sont traités par débridement chirurgical des dépôts hétérotopiques touchés. Le terme dysraphie spinale (DS) décrit toute une série de malformations congénitales du tube neural, du spina-bifida occulte à la forme la plus grave, le mélingomyélocèle. La cause de la DS est multifactorielle et s'associe à des troubles chromosomiques, à une exposition tératogène et à une carence en folates. De nombreux patients ayant une DS souffrent d'une neuropathie sous le niveau neurologique touché, ce qui les rend particulièrement vulnérables aux plaies de pression. Si ces plaies sont graves et ne réagissent pas aux traitements conservateurs, elles doivent souvent faire l'objet d'un débridement chirurgical et d'une reconstruction au moyen d'un lambeau, un scénario clinique rarement responsable d'une $\mathrm{OH}$.

Le présent article décrit le cas d'un patient ayant une OS pelvienne après la reconstruction d'une plaie de pression au moyen d'un lambeau myocutané. Le patient s'est rétabli grâce à un traitement au bisphosphonate par voie orale et une physiothérapie énergique.

\section{CASE PRESENTATION}

A 16-year-old Caucasian boy with a diagnosis of spinal dysraphism at the L5 level presented with a two-month history of a recurrent right ischial pressure ulcer. His surgical history included debridement and flap reconstruction of previous sacral and right ischial ulcers. On physical examination, a stage IV pressure ulcer was present overlying the right ischium in the setting of local postsurgical scarring. Computed tomography confirmed right ischial osteomyelitis. The patient was treated with wide surgical debridement of the involved soft tissues, ostectomy of the right ischial tuberosity and right gluteus maximus myocutaneous flap reconstruction, with postoperative care in the prone and lateral positions. Three months postoperatively, the patient complained of limited hip mobility; a plain pelvis radiograph confirmed bilateral heterotopic ossification $(\mathrm{HO})$ of the iliac crests to the femurs (Figure 1). The patient was subsequently treated with a six-month course of aggressive physical therapy (twice a day treatment sessions) and oral bisphosphonate (etidronate $20 \mathrm{mg} / \mathrm{kg}$ three times a day), which resulted in significant clinical and radiographic improvement of bilateral hip range of motion (Figure 2).

\section{DISCUSSION}

HO has traditionally been a challenging diagnosis to successfully treat. Surgical excision has been described as the treatment of choice for symptomatic $\mathrm{HO}(1,2)$. As with all invasive surgical procedures, there is a risk of infection and blood loss (1), a considerable rehabilitation process and accumulation of scar tissue. Furthermore, due to the high recurrence rates, if surgical resection is performed on an immature lesion, treatment is often delayed for months before operative intervention is performed on mature lesions (3).

Another option is radiation treatment, which can be used for both therapeutic and prophylactic purposes in $\mathrm{HO}(4-6)$. The therapeutic use of radiation therapy in established $\mathrm{HO}$ was first described by Schaeffer and Sosner (5) in 1995, who found that giving a 2 gray dose of radiation for several consecutive days resulted in improved range of motion. For prophylactic therapy, a single dose of 700 centigray administered within $48 \mathrm{~h}$ postoperatively is effective at reducing the recurrence rate of $\mathrm{HO}$ (7). Side effects of radiation therapy are common and present an obvious limitation to this treatment modality. An alternative postoperative prophylactic option is a course of a nonsteroidal anti-inflammatory

${ }^{1}$ Faculty of Medicine, University of British Columbia, Vancouver, British Columbia; ${ }^{2}$ Department of Orthopedics, Children's Hospital of Michigan, Detroit, Michigan, USA; ${ }^{3}$ Division of Plastic Surgery, British Columbia Children's Hospital and University of British Columbia, Vancouver, British Columbia

Correspondence: Dr Jugpal S Arneja, Division of Plastic Surgery, British Columbia Children's Hospital, A237 Shaughnessy Building, Box 150, 4480 Oak Street, Vancouver, British Columbia V6H 3V4. Telephone 604-875-2794, fax 604-875-2749, e-mail jugpal.arneja@ubc.ca 


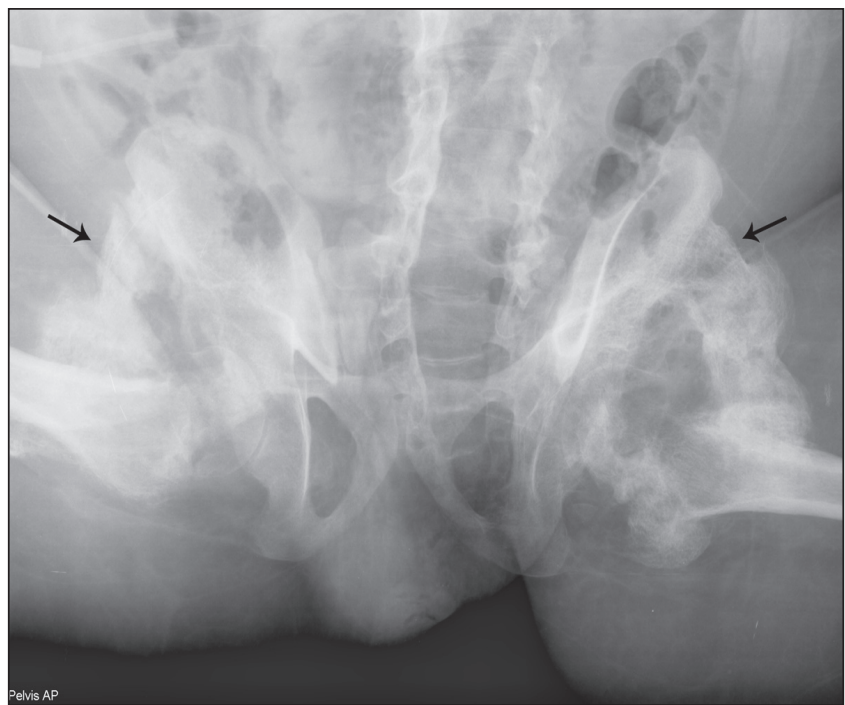

Figure 1) Pelvis radiograph showing large heterotopic ossification from the iliac crest to the femoral head (arrows) before commencing physiotherapy and bisphosphonate therapy

drug such as indomethacin (6). It is generally recommended to initiate anti-inflammatory drug therapy within one day of surgery and to continue for a minimum of three weeks (8).

Our patient exhibited significant clinical and radiological improvement in his HO-related symptoms following aggressive physiotherapy and bisphosphonate treatment. Follow-up at three years post-therapy revealed no signs of recurrence, suggesting that this form of treatment has the potential to be successful in the long term.

The pharmacological mechanism by which bisphosphonates act to improve $\mathrm{HO}$ remains unclear. They are purported to act through a combination of factors such as delaying apatite crystal aggregation, inhibiting calcium phosphate precipitation and reducing the conversion of calcium phosphate into hydroxyapatite (9). Previous studies $(10,11)$ have shown that bisphosphonate therapy can slow the progression of $\mathrm{HO}$ and ultimately result in smaller lesions, although long-term outcomes were not documented. Previous studies have also not provided long-term evidence that bisphosphonate therapy can reduce the size of established HO (11). One concern is the reported 'rebound ossification' that can occur on cessation of bisphosphonate therapy (12). We did not experience this with our patient who remained recurrence free from his $\mathrm{HO}$ and his pressure ulcer three years postoperatively. It is likely that aggressive physiotherapy, which has been used in patients with $\mathrm{HO}$ to improve range of motion and decrease recurrence (9), had a synergistic effect with bisphosphonate therapy.

The outcome of the present case suggests that nonsurgical options for the treatment of established $\mathrm{HO}$ are possible. Given the inherent course and complications associated with either surgery or radiation therapy, and considering the low-risk nature of physiotherapy and bisphosphonates, the latter may be suitable as an initial therapeutic option for symptomatic HO. Certainly, if this nonsurgical treatment is unsuccessful, then either surgery or radiation should be considered. We hypothesize that combined physiotherapy and bisphosphonate therapy have a prophylactic role in patients at high risk for $\mathrm{HO}$ such as those undergoing hip arthroplasty.

The present case demonstrates that it is possible to successfully manage $\mathrm{HO}$ without invasive surgery using aggressive physiotherapy and bisphosphonate therapy. However, when discussing treatment and prevention strategies for $\mathrm{HO}$, it is important to recognize the specific etiology of the disease because the various forms of $\mathrm{HO}$ often respond differently to treatment $(3,13)$. In our case, the patient's lesion could be classified as both traumatic myositis ossificans (myocutaneous flap surgery) and myositis ossificans associated with a nervous system injury (spinal dysraphism). Further studies are needed to validate this treatment

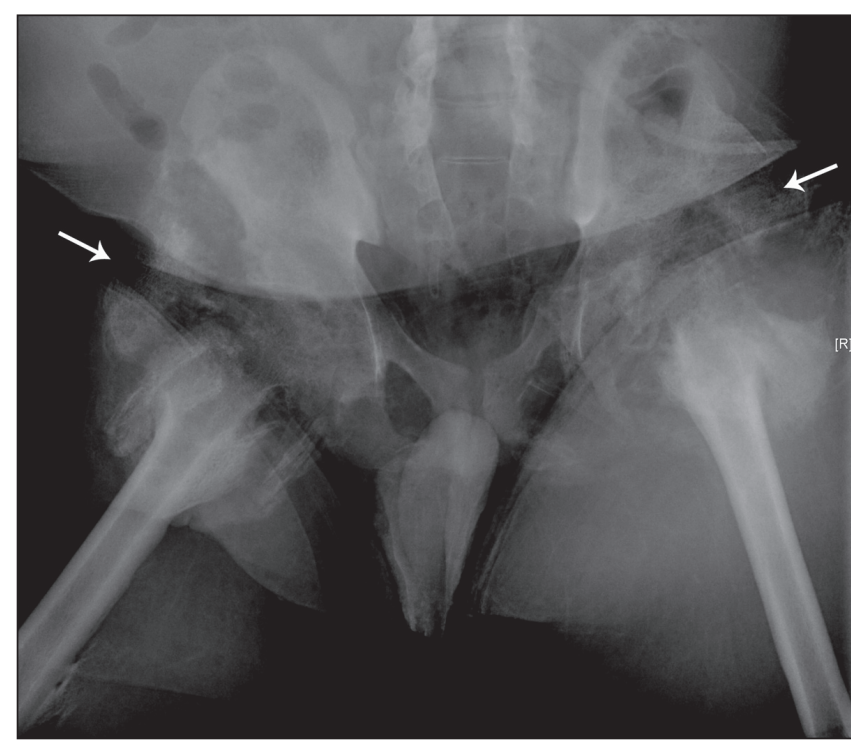

Figure 2) Pelvis radiograph showing significant reduction of heterotopic ossification and correction of femur position in relation to the pelvis (arrows) six months after commencing aggressive physiotherapy and bisphosphonate therapy

option using a larger cohort of patients and to explore its use in other forms of $\mathrm{HO}$, as well as $\mathrm{HO}$ associated with other joints such as the elbow and knee.

DISCLOSURE: The authors have no conflicts of interest to declare.

\section{REFERENCES}

1. Appelt EA, Kenkel JM, Ballard JR, Lopez JA, Anthony T, Castillo T. Preoperative embolization of heterotopic ossification for the treatment of a recalcitrant pressure sore. Plast Reconstr Surg 2005;116:50e-53e.

2. Chen HC, Yang JY, Chuang SS, Huang CY, Yang SY.

Heterotopic ossification in burns: Our experience and literature reviews. Burns 2009;35:857-62.

3. Gear AJ, Buckley C, Kaplan F, Vanbeek A. Multifactorial refractory heterotopic ossification. Ann Plast Surg 2004;52:319-24.

4. Jang SH, Shin SW, Ahn SH, Cho IH, Kim SH. Radiation therapy for heterotopic ossification in a patient with traumatic brain injury. Yonsei Med J 2000;41:536-9.

5. Schaeffer MA, Sosner J. Heterotopic ossification: Treatment of established bone with radiation therapy. Arch Phys Med Rehabil 1995;76:284-6.

6. Vavken P, Castellani L, Sculco TP. Prophylaxis of heterotopic ossification of the hip: Systematic review and meta-analysis. Clin Orthop Relat Res 2009;467:3282-9.

7. Healy WL, Lo TC, DeSimone AA, Rask B, Pfeifer BA. Single-dose irradiation for the prevention of heterotopic ossification after total hip arthroplasty. A comparison of doses of five hundred and fifty and seven hundred centigray. J Bone Joint Surg Am 1995;77:590-5.

8. Kjaersgaard-Andersen P, Schmidt SA. Total hip arthroplasty. The role of anti-inflammatory medications in the prevention of heterotopic ossification. Clin Orthop Relat Res 1991;263:78-86.

9. Ellerin BE, Helfet D, Parikh S, et al. Current therapy in the management of heterotopic ossification of the elbow: A review with case studies. Am J Phys Med Rehabil 1999;78:259-71.

10. Stover SL, Niemann KM, Miller JM III. Disodium etidronate in the prevention of postoperative recurrence of heterotopic ossification in spinal-cord injury patients. J Bone Joint Surg Am 1976;58:683-8.

11. Haran M, Bhuta T, Lee B. Pharmacological interventions for treating acute heterotopic ossification. Cochrane Database Syst Rev 2004;(4):CD003321.

12. van Kuijk AA, Geurts AC, van Kuppevelt HJ. Neurogenic heterotopic ossification in spinal cord injury. Spinal Cord 2002;40:313-26.

13. Cipriano C, Pill SG, Rosenstock J, Keenan MA. Radiation therapy for preventing recurrence of neurogenic heterotopic ossification. Orthopedics 2009;32. 